\title{
First record of Ornithonyssus bursa (Berlese, 1888) (Mesostigmata: Macronyssidae) parasitizing invasive monk parakeets in Santiago, Chile
}

\author{
Primeiro registro de Ornithonyssus bursa (Berlese, 1888) (Mesostigmata: \\ Macronyssidae) parasitando caturritas invasoras em Santiago, Chile.
}
Cristóbal Briceño1* (1); Karina Yévenes; Matilde Larraechea; Alejandra Sandoval-Rodríguez; María Carolina Silva-de la Fuente²; Fernando Fredes³; Héctor Hidalgo4; Valeria Alcayaga4; Pablo Oyarzún-Ruiz ${ }^{5}$; ; Cintia Munita ${ }^{1}$; Daniel González-Acuña ${ }^{5} \dagger$ (D)

\author{
${ }^{1}$ ConserLab, Departamento de Medicina Preventiva Animal, Facultad de Ciencias Veterinarias y Pecuarias, Universidad de Chile, \\ Santiago, Chile \\ ${ }^{2}$ Instituto de Medicina Preventiva Veterinaria, Facultad de Ciencias Veterinarias, Universidad Austral de Chile, Valdivia, Chile \\ ${ }^{3}$ Unidad de Parasitología, Departamento de Medicina Preventiva Animal, Facultad de Ciencias Veterinarias y Pecuarias, Universidad de \\ Chile, Santiago, Chile \\ ${ }^{4}$ Patología Aviar, Departamento de Patología Animal, Facultad de Ciencias Veterinarias y Pecuarias, Universidad de Chile, \\ Santiago, Chile \\ ${ }^{5}$ Laboratorio de Parásitos y Enfermedades en Fauna Silvestre, Facultad de Ciencias Veterinarias, Universidad de Concepción, \\ Chillán, Chile
}

How to cite: Briceño C, Yévenes K, Larraechea M, Sandoval-Rodríguez A, Silva-de la Fuente MC, Fredes F, et al. First record of Ornithonyssus bursa (Berlese, 1888) (Mesostigmata: Macronyssidae) parasitizing invasive monk parakeets in Santiago, Chile. Braz J Vet Parasitol 2021; 30(1): e024020. https://doi.org/10.1590/S1984-29612021023

\begin{abstract}
Myiopsitta monachus is an invasive psittacine with wide distribution due to the pet trade. Its large communal nests and synanthropic nature contribute to its successful colonization of cities, from where it seems to be expanding in range and numbers. This is relevant with regard to pathogens that invasive species may harbor, especially when host populations thrive. We aimed to identify an abundant mite found in invasive monk parakeet chicks that had been collected in Santiago during 2017 and 2018. Through morphological and molecular identification of the $18 \mathrm{~S}$ ribosomal RNA gene, we confirmed the presence of Ornithonyssus bursa. This was the first report of this mite in Chile. This mite is common in native and invasive monk parakeet populations and may affect other birds, including domestic fowl. Further, this mite bites people and can be a potential vector of pathogens such as bacteria or viruses. We conclude that this parasite was likely introduced with the parakeet and discuss possible ecological, health and economic consequences of this new potential pest.
\end{abstract}

Keywords: Invasive species, monk parakeet, tropical fowl mite, Chile.

\section{Resumo}

Myiopsitta monachus é um psitacídeo invasor amplamente distribuído devido ao tráfico de animais selvagens. Os grandes ninhos comunitários construídos e sua condição de espécies sinantrópicas contribuem para a colonização bem-sucedida das cidades, onde parece estar expandindo sua distribuição e número de indivíduos. Isso é relevante, quando se trata de patógenos que os invasores podem abrigar, especialmente quando as populações hospedeiras prosperam. O objetivo deste trabalho foi identificar um ácaro abundante, encontrado em filhotes de periquitos-monge introduzidos em Santiago, Chile, coletados durante 2017 e 2018. Por meio da identificação morfológica e molecular do gene do RNA ribossômico 18S, foi confirmada a presença de Ornithonyssus bursa, sendo o primeiro registro para o Chile. Esse ácaro é comum em populações nativas e introduzidas de periquitos-monge e pode afetar outras aves, incluindo aves domésticas. Além disso, esse ácaro

Received October 13, 2020. Accepted February 8, 2021

*Corresponding author: Cristóbal Briceño. E-mail: cristobal.briceno@uchile.cl

tIn memoriam 
pode picar pessoas e pode ser um potencial vetor de patógenos, como bactérias ou vírus. Conclui-se que esse parasita provavelmente foi introduzido com o periquito e foram discutidas as possíveis consequências ecológicas de saúde e econômicas dessa nova praga em potencial.

Palavras-chave: Espécies invasoras, periquito-monge, ácaro de aves tropicais, Chile.

\section{Introduction}

Invasive species are considered to be the second largest cause of biodiversity loss globally (Vitousek et al., 1997) and the first in biogeographic islands (Vitousek, 1988). Central Chile is recognized as a biogeographic subregion, and Santiago province is one of its two biogeographic units (Morrone, 2006). These unique habitats are considered to be a valuable global ecoregion (Olson \& Dinerstein, 1998). Central Chile is now identified as one of the 25 biodiversity hotspots of highest conservation priority, due its high levels of endemism and high anthropic pressure (Myers et al., 2000). Nonetheless, threats to Chilean biodiversity are still underestimated (Brooks et al., 2002).

Biological invasions relate to the emergence of diseases (Dunn \& Hatcher 2015) that have the potential to contribute to wildlife extinctions, particularly when they interact with additional driving factors (Daszak et al., 2000, Harvell et al., 2002; Smith et al., 2009). In this regard, invasive species have been identified as sources of spread of zoonoses. Thus, these species have the potential to affect the health of animals and people (Keesing et al., 2010; Dunn \& Hatcher 2015; Estrada-Peña et al., 2014). Consequently, invasive parasites are also considered to constitute biological invasions, with a crucial role in species loss (Taraschewski, 2006; Landaeta-Aqueveque et al., 2018).

Monk parakeets are widely distributed as an invasive species as a consequence of the pet trade (Edelaar et al., 2015). Currently, alien populations are found in 19 countries (ISSG, 2015). These parakeets are considered to be ecosystem engineers (Briceño et al., 2019) because of their unique ability among psittacids for building large communal nests weighing up to several hundred kilograms (Spreyer \& Bucher, 1998). These nests are entwined with twigs and branches by a parakeet couple or several family members, to construct chambers that may be aggregated over several seasons, thus enlarging these nests (Spreyer \& Bucher, 1998). Monk parakeets use their nests for breeding and roosting year-round (Navarro et al., 1995) and are considered to be highly philopatric (Martin \& Bucher, 1993). This bird species is deemed to be synanthropic (Briceño et al., 2019) and thus is mainly found in urban environments. However, they may also have an important impact in rural areas, as observed in their native distribution in Argentina, where they are considered to produce US\$1 billion of annual costs associated with crop losses (Iriarte et al., 2005).

In Chile, the invasive population of monk parakeets grew from pets that were released in eastern Santiago during the early 1980s (Iriarte et al., 2005; Briceño et al., 2017). Official records estimate that at least 15,000 parakeets were imported into Chile, until the species was declared harmful and importation banned. Since then, its major impact has been perceived on fruit and ornamental trees (Iriarte et al., 2005).

Although little is known about monk parakeets' pathogen load and their role in pathogen transmission (Briceño et al., 2017), they have been found to harbor ectoparasites in their area of native distribution, and some are specific to these birds. Hence, in Argentina the cimicid bug Psitticimex uritui (Hemiptera: Cimicidae) has been classified as one of the most abundant parasites of monk parakeet nests, even though it only parasitizes this species (Spreyer \& Bucher, 1998; Aramburú et al., 2003). The blood-sucking mite Ornithonyssus bursa (Acarina: Macronyssidae) has also been described in parakeets' nests in Argentina (Aramburú et al., 2002). Two chewing lice, Heteromenopon macrurum (Phthiraptera: Menopodidae) and Paragoniocotes fulvofasciatum (Phthiraptera: Philopteridae), are permanent parasites of monk parakeets in their area of native distribution (Aramburú et al., 2003). The latter has recently also been found in introduced monk parakeet populations in Chile and Italy (Mori et al., 2015; Briceño et al., 2017). Finally, the soft tick Argas monachus (Ixodoidea: Argasidae) is also specific to monk parakeets and all stages of this parasite have been found dwelling in nests of these birds in Argentina and Paraguay (Keirans et al., 1973; Mastropaolo et al., 2011). Furthermore, in their invasive distribution, monk parakeets are also capable of acquiring local parasites. Consequently, it was found in Rome, Italy, that monk parakeets harbored not only the invasive parasites P. fulvofasciatum and O. bursa, but also the flies Crataerina pallida and Ornithophila metallica (Diptera: Hippoboscidae) and the louse Columbicola columbae (Phthiraptera: Philopteridae) (Ancillotto et al., 2018).

The aim of the present study was to report on the presence of abundant mites found on monk parakeet chicks in Santiago, characterize them morphologically and genetically and discuss the potential ecological and health implications of this blood-sucking mite for local fauna. 


\section{Material and Methods}

\section{Study site}

This study was conducted in the Metropolitan Region of Santiago ( $33^{\circ} 27^{\prime} \mathrm{S} ; 70^{\circ} 38^{\prime} \mathrm{W}$ ), Chile. This region is located in the Mediterranean bioclimatic zone of Central Chile, which is characterized by dry summers and wet winters, with marked interannual variability due to the El Niño-Southern Oscillation phenomenon (Amigo \& Ramírez, 1998). The mean annual temperature is $13.2^{\circ} \mathrm{C}$ and the mean annual precipitation is $531 \mathrm{~mm}$ (Schulz et al., 2010). Temperature and humidity depend upon topography, resulting in a vegetation mosaic of Acacia caven shrubland on lower hillslopes, and evergreen sclerophyllous forest, mainly on watersheds and south-facing slopes (Badano et al., 2005; Schulz et al., 2010).

\section{Sample collection}

As part of a research project aiming to asses monk parakeets' ecological and sanitary impact, monk parakeet nestlings (<40 days old, as suggested by Eberhard (1998) were manually collected from nests throughout the city of Santiago, during two of their reproductive seasons (austral springs of 2017 and 2018). During the collection process, abundant mites on some of the nestlings were noted. These arthropods were collected and preserved in $70 \%$ ethanol. Some of them were subsequently clarified in Nesbitt solution and mounted in Berlese medium (Krantz \& Walter, 2009) for viewing and photographing using bright-field microscopy (Bf; Leica DM1000; Figures 1 and 2) and scanning electron microscopy (SEM; Hitachi SU3500; Figure 1A).

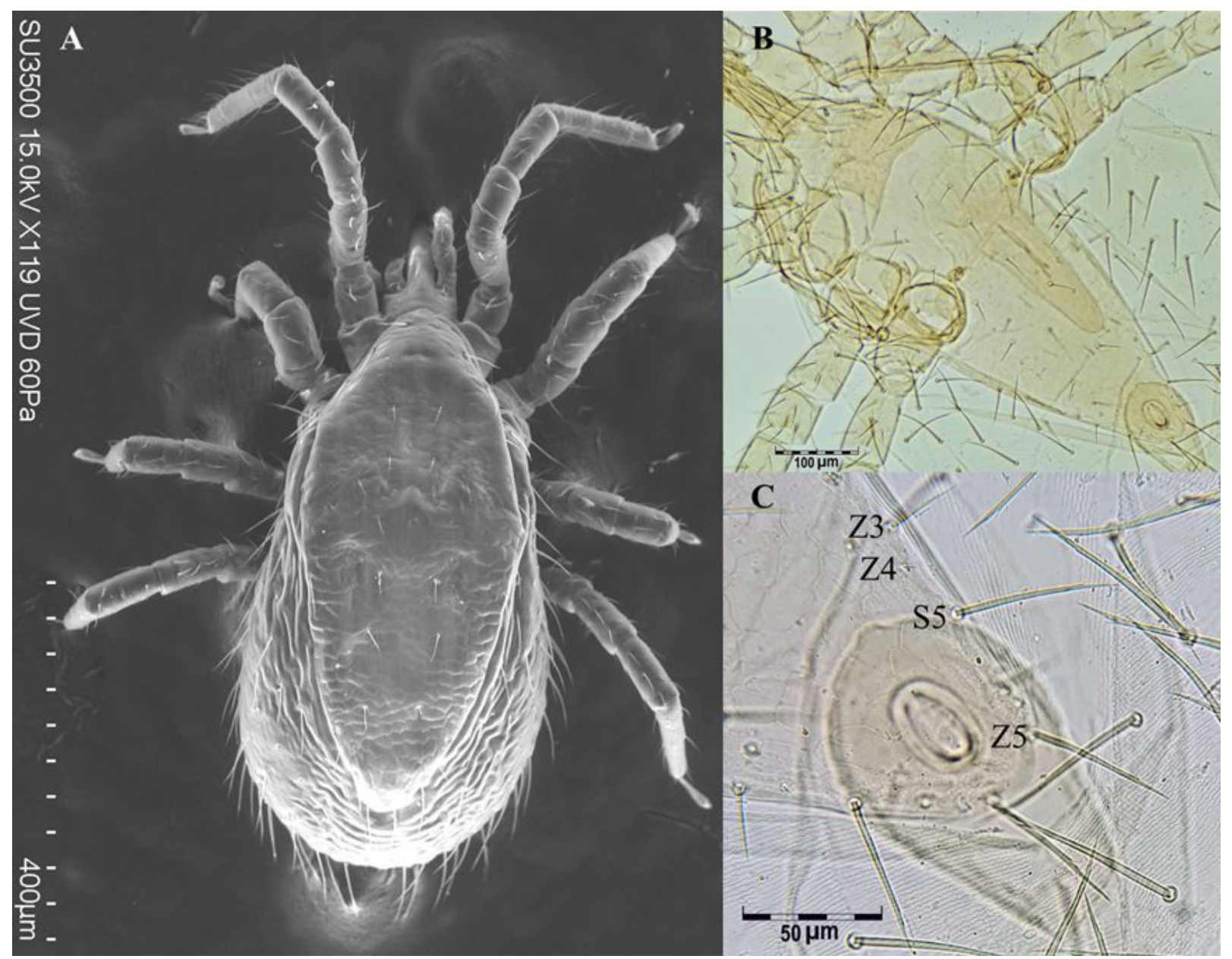

Figure 1. Female of Ornithonyssus bursa. (A) Dorsal general view (SEM); (B) Dorsal general view (Bf); (C) Posterior margin of the dorsal plate with Z3, Z4, Z5 and S5 setae. 


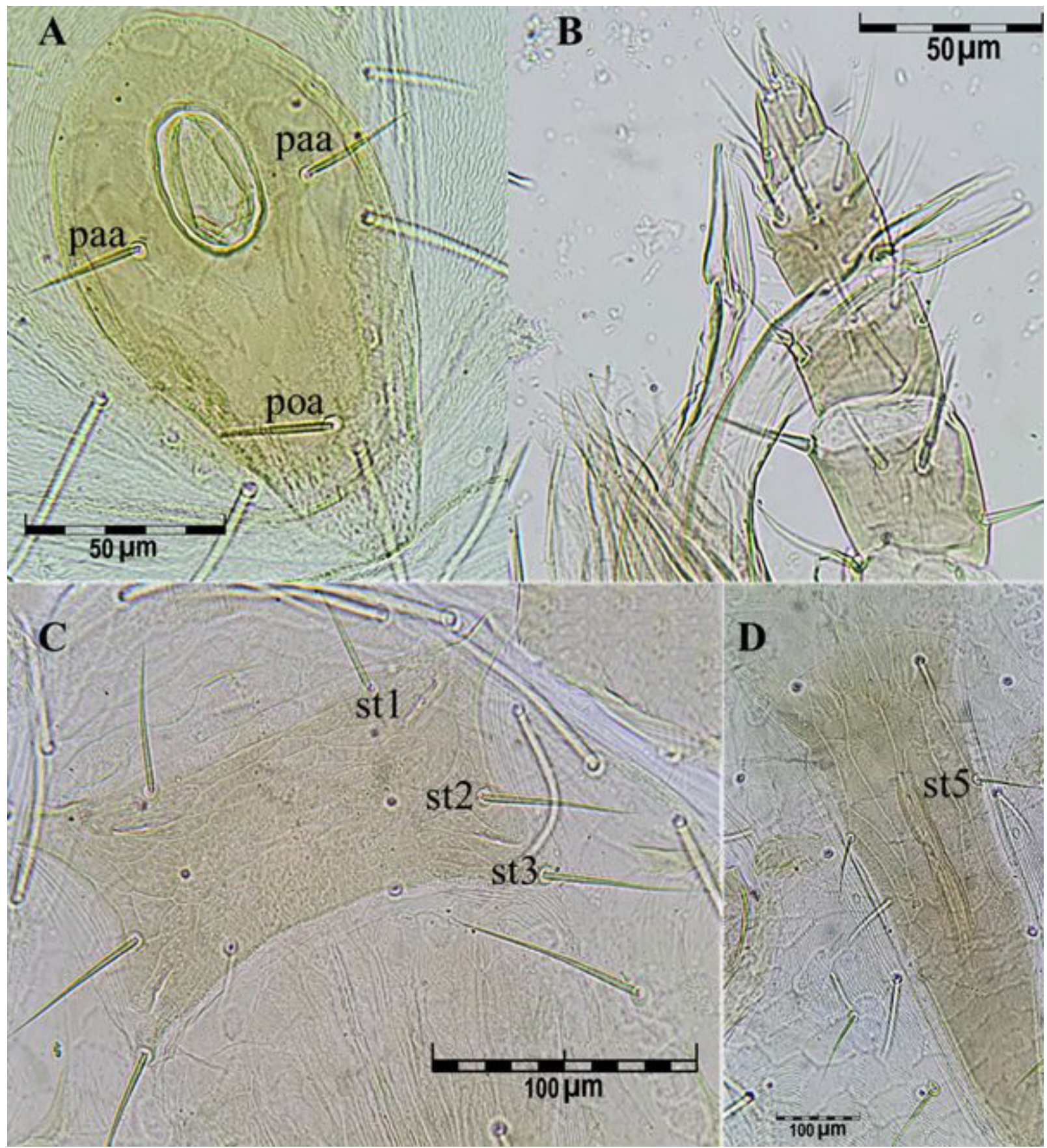

Figure 2. Female of Ornithonyssus bursa. (A) Anal plate with paranal setae (paa) and postanal seta (poa); (B) General view of the chelicera; (C) Sternal plate with three sternal setae (st1-st3); (D) Epigynal plate with epigynal seta (st5).

\section{Molecular analyses}

To contribute to identification of mite species, five mites were individually pressed between two frozen glass slides and squashed for DNA extraction (Briceño et al., 2020). Biological material was retrieved by pipetting $180 \mu \mathrm{L}$ of T1 buffer provided in the NucleoSpin ${ }^{\circledR}$ tissue DNA kit (Macherey-Nagel Ltd., Düren, Germany) on the rim of the slides, and collecting the material through capillary action. Extraction of DNA from each mite was completed using the NucleoSpin ${ }^{\circledR}$ tissue DNA kit, following the manufacturer's instructions.

In order to perform PCR, a fragment of the $18 \mathrm{~S}$ rRNA gene was amplified using the following primers: 5'-CTA TTG GAG GGC AAG TCT GG-3' (forward) and 5' -TGG CAT AGT TTA TGG TTA G-3' (reverse). These are modified versions of the primers Mite18S-1 F and Mite18S-1R published by Otto \& Wilson (2001). PCR was performed using Taq DNA polymerase with the ThermoPol $\circledast$ buffer kit (New England BioLabs $®$ ), following the manufacturer's instructions. 
Reactions were set up in a volume of $25 \mu \mathrm{l}$ and contained the following: $1 \mathrm{X}$ of ThermoPol@ reaction buffer, $200 \mu \mathrm{M}$ of each dNTP, $0.2 \mu \mathrm{M}$ of each primer, $2 \mu \mathrm{L}$ of genomic DNA extracted as described above and 0.625 units of Taq polymerase. Negative controls, in which nuclease-free water was added in place of the DNA template, were used to confirm that no contamination of reagents had occurred. The PCR sequence consisted of a modified version of what was described by Otto \& Wilson (2001): $94^{\circ} \mathrm{C}$ for $1 \mathrm{~min}$; $35 \mathrm{cycles}$ of $94^{\circ} \mathrm{C}$ for $20 \mathrm{sec}, 50^{\circ} \mathrm{C}$ for $30 \mathrm{sec}$ and $72{ }^{\circ} \mathrm{C}$ for $1 \mathrm{~min}$ and 30 secs; and a final elongation cycle of $72^{\circ} \mathrm{C}$ for $5 \mathrm{~min}$. The PCR products were analyzed by separately distributing $5 \mu \mathrm{L}$ of each amplicon on $1.5 \%$ agarose gel stained using GelRed ${ }^{\circledR}$, and visualizing the results under ultraviolet light. Successful PCR reactions (four in total) were then purified using the DNA Clean \& Concentrator ${ }^{\mathrm{TM}}-5$ kit (Zymo Research), following the manufacturer's instructions. Purified PCR products were then sequenced using both forward and reverse primers (Macrogen Inc., Seoul, South Korea). DNA sequences were edited manually by reviewing chromatograms and were aligned using MEGA 7 (Kumar et al., 2016).

\section{Results}

Most of the manually collected monk parakeet chicks had abundant mites on them, as did the nest materials. During transportation to the laboratory for subsequent analyses, many of these mites were found creeping on research team members, who received bites that left marks lasting for days. The mites also remained on the team members' clothing for days. Under a microscope (Figure 1A, B), these were identified as mites of the order Mesostigmata, potentially of the species Ornithonyssus bursa.

The following characteristics were described. Dorsal plate complete with short setae and with gradual distal narrowing, posterior margin of dorsal shield with four pairs of posterior setae, Z4 present and short (Figure 1A-C); sternal plate with three sternal setae inside the plate (Figure 2C); chelicerae not enlarged distally (Figure 2B); epigynal plate with tapered distal end (Figure 2D); anal plate longer than wide (Figure 2A) (Strandtmann \& Wharton, 1958; Denmark \& Cromroy, 2003; Radovsky, 2010; Lareschi et al., 2017; Bassini-Silva et al., 2019).

The preparations were deposited in the Collection of the Animal Science Department (Colección del Departamento de Ciencia Animal, CDCA; Universidad de Concepción, Chillán) under the numbers CDCA-352-353. DNA amplification by means of PCR provided four identical sequences (GenBank accession number MT176123; 457 bp), each obtained from individual mites, with 100\% homology to O. bursa at the 18S ribosomal RNA gene (Reference FJ911854; 1597 bp).

\section{Discussion}

The present manuscript provides the first report of occurrence of the tropical fowl mite (Ornithonyssus bursa Berlese, 1888) in Chile. This mite belongs to the order Mesostigmata and parasitizes passerines and domestic birds (Sreenivasa Murthy \& Panda, 2016). It is found in warmer areas of the world including North, Central and South America, in Argentina, Brazil and Colombia (Aramburú et al., 2002; Mascarenhas et al., 2009; Sreenivasa Murthy \& Panda, 2016; Bassini-Silva et al., 2019; Mesquita-Sousa et al., 2020). It was recently described as an invasive parasite in Italy (Castelli et al., 2015) and Spain (Mori et al., 2019). It has also been found in domestic fowl in Indonesia, India (Sreenivasa Murthy \& Panda, 2016; Selfiannisa et al., 2018) and various locations in Africa and Australia (Denmark \& Cromroy, 2003).

The tropical fowl mite produces feather asymmetry (Proctor \& Owens, 2000), weight loss and reduced numbers of eggs and sperm counts in birds (Sreenivasa Murthy \& Panda, 2016). This parasite may impact the poultry industry (Santillán et al., 2015; Sreenivasa Murthy \& Panda, 2016; Selfiannisa et al., 2018), considering that it has frequently been found parasitizing backyard chickens in Brazil (Guimarães et al., 2001). Moreover, it has the potential to feed on mammals such as mice and rabbits (Sikes \& Chamberlain, 1954).

This parasite also bites humans (Fox, 1957; Oliveira et al., 2012; Castelli et al., 2015; Mentz et al., 2015; BassiniSilva et al., 2019). It can move into houses from nests when these are close to human settlements (Oliveira et al., 2012; Castelli et al., 2015). Because it is hematophagous, it has also the potential to transmit pathogens such as bacteria and viruses (Santillán et al., 2015; Lareschi et al., 2017).

Ornithonyssus bursa has been described in monk parakeets in their area of native distribution (Aramburú et al., 2002). It also affects several bird species with diverse host infestation rates (Santillán et al., 2015). This mite has been detected parasitizing American kestrels (Falco sparverius) (Liébana et al., 2011) and has been found at high prevalence rates (90\%) in native blue-crown parakeet chicks (Aratinga acuticaudata) in Argentina (Aramburú et al., 2003). Also 
in Argentina, this mite has been identified as an ectoparasite of the invasive European starling (Sturnus vulgaris), and further, as vector of Wolbachia sp. bacteria (Lareschi et al., 2017).

The tropical fowl mite is considered to be a common nest parasite of passerines (Proctor \& Owens, 2000), affecting sparrows (Passer domesticus) and northern mockingbirds (Mimus polyglottos) in Florida, USA (Phillis \& Cromroy, 1972), rock pigeons (Columba livia) in Colombia (Pérez-García et al., 2015) and Spain (Mori et al., 2019) and swallows (Hirundo rustica) in Denmark; in the latter it reduced clutch size (Moller, 1991). In New Zealand, it has been found to diminish the body size of chicks of North Island robins (Petroica longipes) and force them to fledge at an early age, thus increasing their vulnerability to predators (Berggren, 2005).

Ornithonyssus bursa has been recently found at a high infectious rate (97\%) in chicks of invasive monk parakeets in Barcelona, Spain (Mori et al., 2019), and it was suggested that this was an invasive parasite. In addition, it seems that $O$. bursa is already established in Europe: human dermatitis cases have already been diagnosed in Sicily (Castelli et al., 2015), where free-ranging invasive monk parakeet populations have been established (ISSG, 2015), thus representing a potential source of the introduced mite. In Rome, introduced urban populations of monk parakeets have also been found to be parasitized by O. bursa (Ancillotto et al., 2018). One alternative hypothesis could be that this mite reached these places carried by migratory birds such as the European starling or the barn swallow (Hirundo rustica), which are known to be hosts of tropical fowl mites (Moller, 2010; Lareschi et al., 2017).

The dynamics of macronyssid mites are strongly influenced by the environment (Arce et al., 2018) and O. bursa has been shown to have decreasing virulence with increasing temperatures (Moller, 2010). This may be relevant in hot environments such as urban Santiago, where some meteorological stations report average maximum temperatures higher than $30^{\circ} \mathrm{C}$ in January and February (McPhee et al., 2014). Here, the tropical fowl mite might find relief in controlled environments. Nest chambers constructed by monk parakeets have been shown to be somewhat controlled environments in relation to external conditions. They are able to buffer maximum ambient temperatures such that the temperature in the nest may be as much as seven degrees lower than the ambient temperature during the breeding season (Viana et al., 2016).

Monk parakeets are known to share space and interact with other birds at the same trees or feeding sites (Briceño et al., 2019; Mori et al., 2019). Because O. bursa is known to be abundant on monk parakeet chicks and in their nests (Aramburú et al., 2003), there is therefore a risk for other birds that use parakeets' nests, given that these ectoparasites can overwinter in nesting holes (Mori et al.. 2019). In Santiago, both native and introduced bird species occupy monk parakeets' nest for breeding (Briceño et al., 2019). Introduced rock pigeons and house sparrows, which are both synanthropic species, are known to become infested with O. bursa mites (Phillis \& Cromroy, 1972; Pérez-García et al., 2015; Santillán et al., 2015; Mori et al., 2019). It is therefore likely that populations of these two introduced species are already affected by this parasite in Santiago. O. bursa was also found in $16 \%$ of a sample of free-ranging native eared doves (Zenaida auriculata) in Brazil (Goulart et al., 2011), although it was not found in an extensive study on the same species in Chile, some $400 \mathrm{~km}$ south of Santiago (González et al., 2004). Eared doves are known to breed in monk parakeets' nests in Santiago (Briceño et al., 2019), so it is also likely that populations in sympatry with monk parakeets may have the mite already.

The American kestrel and Harris's hawk (Parabuteo unicinctus) are predators of monk parakeets (Celis-Diez, 2016; Briceño et al., 2019), even though other birds of prey such as the Austral pigmy owl (Glaucidium nana) and aplomado falcon (Falco femoralis) have been found breeding in monk parakeets' nests (Briceño et al., 2019): These raptors may be at risk through predation on parakeet chicks in an mite-infested environment before nest occupation. In fact, populations of the ferruginous pigmy owl and aplomado falcon in Argentina have been described as hosts of O. bursa (Santillán et al., 2015). Other species that have been found to breed in monk parakeets' nests in Santiago are the American kestrel and the house wren (Troglodytes aedon) (Briceño et al., 2019), which are both species on which O. bursa has been found in Argentina (Santillán et al., 2015). The chimango caracara (Milvago chimango), an abundant bird species that is suspected of thriving in urban and periurban areas and is known to share space and interact with monk parakeets (Briceño et al., 2019), has been found to be parasitized by O. bursa in Argentina, in both chicks and adults (Santillán et al., 2015).

Monk parakeets are highly gregarious, and $O$. bursa has been found to be more abundant in denser populations of monk parakeets (Ancillotto et al., 2018; Mori et al., 2019). Also, introduced populations of monk parakeets seem to have higher reproductive rates, resulting in denser populations than in their areas of native distribution (Senar et al., 2019). Rock pigeons have been shown to have higher abundance of ectoparasites in areas of higher monk parakeet densities (Mori et al., 2019), and this could apply to other species as well. Moreover, in Barcelona, 
the 0 . bursa infection rate in rock pigeons was $10 \%$. Because this is a wide ranging bird, it has the potential to spread O. bursa over large areas, even outside urban settlements (Mori et al., 2019).

Although field studies have determined that the tropical fowl mite has some degree of affinity for certain host species, the bird species with the highest mite prevalences are not the ones presenting the highest mite intensity. Additionally, it appears that nestlings of bird species with higher mite prevalences are the ones with higher encounter rates (Arce et al., 2018). This could also be relevant in relation to gregarious species such as the monk parakeet, which in its invasive distribution seems to have higher densities of nestlings, as well as longer reproductive periods (Senar et al., 2019).

Even though in this study we did not quantify the intensity of mite infestation, it appears that the abundance was greater (we retrieved many mites from the chicks) than the one mite that was found among ninety-two adult monk parakeets collected in Santiago during 2006 and 2007 (Briceño et al., 2017). This finding is consistent with the biology of the parasite, which mainly affects non-flying chicks (Aramburú et al., 2003). Nonetheless, a couple of mite individuals on adult birds is all that is required for mite abundance to increase rapidly (Arce et al., 2018).

0 . bursa has been found at high prevalence in native and invasive populations of monk parakeet nestlings in Argentina (48\%) (Aramburú et al., 2003) and Barcelona (97\%) (Mori et al., 2019), respectively. Moreover, these parakeets' nests are occupied by several other species (Briceño et al., 2019). It therefore seems more likely that $O$. bursa is a co-introduced parasite (with $M$. monachus), with the potential to become a co-invasive parasite that infects native birds (Lymbery et al., 2014).

This was the first report of $O$. bursa in Chile, found in monk parakeets' nestlings. The monk parakeet is considered to be one of the most invasive bird species, in part due to its condition of being an ecosystem engineer (Briceño et al., 2019). Invasive monk parakeet populations produce economic losses (Iriarte et al., 2005; Senar et al., 2019), although little is known about their impact on animal or public health (Briceño et al., 2017). This species continues to expand its distribution in Santiago, with consequent potential spread of the tropical fowl mite. This hematophagous mite has the potential to affect the conservation of native and/or endangered bird species through increased predation, due to forced early fledging of nestlings (Berggren, 2005). It also has the potential to affect the health status of resident birds, not only through blood sucking but also as a potential vector of pathogens, with possible risk for other animals, including humans (Fox, 1957; Oliveira et al., 2012; Castelli et al., 2015; Mentz et al., 2015; Bassini-Silva et al., 2019). Finally, our finding is also of concern for the poultry industry, which may become affected by this introduced parasite. These impacts may already be happening and further studies to understand them in detail are warranted.

\section{Acknowledgements}

This research was funded by FONDECYT Initiation No. 11160852 from the National Commission for Science and Technology of Chile (CONICYT). We are grateful to Ramón Molina, Fernando Navarrete, Patricio Toro, Pablo Dufflocq, Catalina Chappuzzeau, Angello Morgado and Florencia Olivares.

The authors express their gratitude to the communes of La Reina, Peñalolén, Las Condes, Providencia, La Pintana, San Miguel, La Florida, La Cisterna, La Granja, Recoleta, Santiago, Puente Alto, San Bernardo, Maipú, Huechuraba, Independencia, Macul and Conchalí for their logistic support and collaboration during the sampling process. Finally, the authors would also like to thank all citizens who provided valuable information on monk parakeet nest locations.

\section{References}

Amigo J, Ramírez C. A bioclimatic classification of Chile: woodland communities in the temperate zone. Plant Ecol 1998; 136(1): 9-26. http://dx.doi.org/10.1023/A:1009714201917.

Ancillotto L, Studer V, Howard T, Smith VS, McAlister E, Beccaloni J, et al. Environmental drivers of parasite load and species richness in introduced parakeets in an urban landscape. Parasitol Res 2018; 117(11): 3591-3599. http://dx.doi.org/10.1007/ s00436-018-6058-5. PMid:30167793.

Aramburú R, Calvo S, Alzugaray ME, Cicchino A. Ectoparasitic load of monk parakeet (Myiopsitta monachus, Psittacidae) nestlings. Ornitol Neotrop 2003; 14(3): 415-418.

Aramburú R, Cicchino A, Bucher E. Material Vegetal Fresco En Cámaras De Cría De La Cotorra Argentina Myiopsitta monachus (Psittacidae). Ornitol Neotrop 2002; 13(4): 433-436. 
Arce SI, Manzoli DE, Saravia-Pietropaolo MJ, Quiroga MA, Antoniazzi LR, Lareschi M, et al. The tropical fowl mite, Ornithonyssus bursa (Acari : Macronyssidae): environmental and host factors associated with its occurrence in Argentine passerine communities. Parasitol Res 2018; 117(10): 32573267. http://dx.doi.org/10.1007/s00436-018-6025-1. PMid:30069828.

Badano El, Cavieres LA, Molina-Montenegro MA, Quiroz CL. Slope aspect influences plant association patterns in the Mediterranean matorral of central Chile. J Arid Environ 2005; 62(1): 93-108. http://dx.doi.org/10.1016/j.jaridenv.2004.10.012.

Bassini-Silva R, Jacinavicius FC, Hernandes FA, Ochoa R, Bauchan GR, Dowling APG, et al. Dermatitis in humans caused by Ornithonyssus bursa (Berlese 1888) (Mesostigmata: Macronyssidae) and new records from Brazil. Rev Bras Parasitol Vet 2019; 28(1): 134-139. http://dx.doi.org/10.1590/s1984-296120180097. PMid:30785556.

Berggren $\AA$. Effect of the blood-sucking mite Ornithonyssus bursa on chick growth and fledging age in the North Island robin. $N$ ZJ Ecol 2005; 29(2): 243-250.

Briceño C, González-Acuña D, Jiménez JE, Bornscheuer ML, Funk SM, Knapp LA. Ear mite, Otodectes cynotis, on wild foxes (Pseudalopex spp.) in Chile.J Wildl Dis 2020; 56(1): 105-112. http://dx.doi.org/10.7589/2018-10-247. PMid:31329523.

Briceño C, Sandoval-Rodríguez A, Yévenes K, Larraechea M, Morgado A, Chappuzeau CV, et al. Interactions between invasive Monk Parakeets (Myiopsitta monachus) and Other Bird Species during Nesting Seasons in Santiago, Chile. Animals (Basel) 2019; 9(11): 923. http://dx.doi.org/10.3390/ani9110923. PMid:31694253.

Briceño C, Surot D, González-Acuña D, Martínez FJ, Fredes F. Parasitic survey on introduced monk parakeets (Myiopsitta monachus) in Santiago, Chile. Rev Bras Parasitol Vet 2017; 26(2): 129-135. http://dx.doi.org/10.1590/s1984-29612017023. PMid:28746442.

Brooks TM, Mittermeier RA, Mittermeier CG, da Fonseca GAB, Rylands AB, Konstant WR, et al. Habitat loss and extinction in the hotspots of biodiversity. Conserv Biol 2002; 16(4): 909-923. http://dx.doi.org/10.1046/j.1523-1739.2002.00530.x.

Castelli E, Viviano E, Torina A, Caputo V, Bongiorno MR. Avian mite dermatitis: an Italian case indicating the establishment and spread of Ornithonyssus bursa (Acari: Gamasida: Macronyssidae) (Berlese, 1888) in Europe. Int J Dermatol 2015; 54(7): 795-799. http://dx.doi.org/10.1111/ijd.12739. PMid:25660724.

Celis-Diez J. Observación de cernícalos (Falco sparverius) depredando polluelos de cotorra Argentina (Myiopsitta monachus) en parques urbanos de Santiago. Bol Chileno Ornitol 2016; 20(1-2): 23-24.

Daszak P, Cunningham AA, Hyatt AD. Emerging infectious diseases of wildlife-- threats to biodiversity and human health. Science 2000; 287(5452): 443-449. http://dx.doi.org/10.1126/science.287.5452.443. PMid:10642539.

Denmark HA, Cromroy HL. Tropical Fowl Mite, Ornithonyssus bursa (Berlese) (Arachnida: Acari: Macronyssidae). IFAS Extension [online] 2003 [cited 2020 Dec 11];297: 1-3. Available from: https://edis.ifas.ufl.edu/in575

Dunn AM, Hatcher MJ. Parasites and biological invasions: parallels, interactions, and control. Trends Parasitol 2015; 31(5): 189199. https://doi.org/10.1016/j.pt.2014.12.003.

Eberhard JR. Breeding biology of the monk parakeet. Wilson Bull 1998; 110(4): 463-473.

Edelaar P, Roques S, Hobson EA, Gonçalves da Silva A, Avery ML, Russello MA, et al. Shared genetic diversity across the global invasive range of the monk parakeet suggests a common restricted geographic origin and the possibility of convergent selection. Mol Ecol 2015; 24(9): 2164-2176. http://dx.doi.org/10.1111/mec.13157. PMid:25873354.

Estrada-Peña A, Ostfeld RS, Peterson AT, Poulin R, de la Fuente J. Effects of environmental change on zoonotic disease risk: an ecological primer. Trends Parasitol 2014; 30(4): 205-214. http://dx.doi.org/10.1016/j.pt.2014.02.003. PMid:24636356.

Fox I. Ornithonyssus bursa (Berlese) attacking man in Puerto Rico. J Econ Entomol 1957; 50(6): 838. http://dx.doi.org/10.1093/ jee/50.6.838.

González D, Daugschies A, Rubilar L, Pohlmeyer K, Skewes O, Mey E. Fauna parasitaria de la tórtola común (Zenaida auriculata, de Murs 1847) (Columbiformes: Columbidae) en Ñuble, Chile. Parasito/ Latinoam 2004; 59(1-2): 37-41. http://dx.doi.org/10.4067/ S0717-77122004000100007.

Goulart TM, Moraes DL, Prado AP. Mites associated with the eared dove, Zenaida auriculata (Des Murs, 1847), in São Paulo State, Brazil. Zoosymposia 2011; 6(1): 267-274. http://dx.doi.org/10.11646/zoosymposia.6.1.36.

Guimarães J, Barros-Battesti D, Tucci E. Ectoparasitos de importância veterinária. São Paulo: Editora Plêiade Ltda; 2001.

Harvell CD, Mitchell CE, Ward JR, Altizer S, Dobson AP, Ostfeld RS, et al. Climate warming and disease risks for terrestrial and marine biota. Science 2002; 296(5576): 2158-2162. http://dx.doi.org/10.1126/science.1063699. PMid:12077394.

Invasive Species Specialist Group - ISSG. Global Invasive Species Database. Myiopsita monachus (monk parakeet) [online]. 2015 [cited 2020 Nov 5]. Available from: http://www.iucngisd.org/gisd/speciesname/myiopsitta+monachus

Iriarte JA, Lobos GA, Jaksic FM. Invasive vertebrate species in Chile and their control and monitoring by governmental agencies. Rev Chil Hist Nat 2005; 78(1): 143-154. http://dx.doi.org/10.4067/S0716-078X2005000100010. 
Keesing F, Belden LK, Daszak P, Dobson A, Harvell CD, Holt RD, et al. Impacts of biodiversity on the emergence and transmission of infectious diseases. Nature 2010; 468(7324): 647-652. http://dx.doi.org/10.1038/nature09575. PMid:21124449.

Keirans JE, Radovsky FJ, Clifford CM. Argas (Argas) monachus, new species (Ixodoidea: Argasidae), from nests of the monk parakeet, Myiopsitta monachus, in Argentina.J Med Entomol 1973; 10(5): 511-516. http://dx.doi.org/10.1093/jmedent/10.5.511. PMid:4760629.

Krantz GW, Walter DE. A manual of acarology. 3rd ed. Lubbock, Texas: Texas Tech University Press; 2009.

Kumar S, Stecher G, Tamura K. MEGA7: molecular evolutionary genetics analysis version 7.0 for Bigger Datasets. Mol Biol Evol 2016; 33(7): 1870-1874. http://dx.doi.org/10.1093/molbev/msw054. PMid:27004904.

Landaeta-Aqueveque C, Robles MR, Henríquez A, Yáñez-Meza A, Correa JP, González-Acuña D, et al. Phylogenetic and ecological factors affecting the sharing of helminths between native and introduced rodents in Central Chile. Parasitology 2018; 145(12): 1570-1576. http://dx.doi.org/10.1017/S0031182018000446. PMid:29886859.

Lareschi M, Cicuttin GL, De Salvo MN, Ibañez L, Montalti D. The tropical fowl mite Ornithonyssus bursa (Acari: Mesostigmata: Macronyssidae) parasitizing the European starling Sturnus vulgaris (Aves: Passeriformes: Sturnidae), an invasive bird in central Argentina. An approach to the bacterial fauna of this mite. Rev Mex Biodivers 2017; 88(2): 454-458. https://doi.org/10.1016/j. rmb.2017.03.022.

Liébana MS, Santillán MÁ, Cicchino AC, Sarasola JH, Martínez P, Cabezas S, et al. Ectoparasites In free-ranging american kestrels in Argentina: implications for the transmission of viral diseases. J Raptor Res 2011; 45(4): 335-341. http://dx.doi.org/10.3356/ JRR-11-26.1.

Lymbery AJ, Morine M, Kanani HG, Beatty SJ, Morgan DL. Co-invaders: the effects of alien parasites on native hosts. Int J Parasitol Parasites Wildl 2014; 3(2): 171-177. http://dx.doi.org/10.1016/j.ijppaw.2014.04.002. PMid:25180161.

Martin LF, Bucher EH. Natal dispersal and first breeding age in monk parakeets. Auk 1993; 110(4): 930-933. http://dx.doi. org/10.2307/4088651.

Mascarenhas CS, Coimbra MAA, Müller G, Brum JGW. Ocorrência de Ornithonyssus bursa (Berlese, 1888) (Acari: Macronyssidae) em filhotes de Megascops choliba (corujinha-do-mato) e Pitangus sulphuratus (bem-te-vi), no Rio Grande do Sul, Brasil. Rev Bras Parasitol Vet 2009; 18(4): 69-70. https://doi.org/10.4322/rbpv.01804013.

Mastropaolo M, Turienzo P, Di lorio O, Nava S, Venzal JM, Guglielmone AA, et al. Distribution and 16S rDNA sequences of Argas monachus (Acari: Argasidae), a soft tick parasite of Myiopsitta monachus (Aves: Psittacidae). Exp Appl Acarol 2011; 55(3): 283-291. https://doi.org/10.1007/s10493-011-9469-x.

McPhee J, Cortés G, Rojas M, Garcia L, Descalzi A, Vargas L. Downscaling climate changes for Santiago: What effects can be expected? In: Krellenberg K, Hansjürgens B, editors. Climate adaptation Santiago. New York: Springer Berlin Heidelberg; 2014. p. 19-41. http://dx.doi.org/10.1007/978-3-642-39103-3_2.

Mentz MB, Silva GL, Silva CE. Dermatitis caused by the tropical fowl mite Ornithonyssus bursa (Berlese) (Acari: Macronyssidae): a case report in humans. Rev Soc Bras Med Trop 2015; 48(6): 786-788. http://dx.doi.org/10.1590/0037-8682-0170-2015. PMid:26676510.

Mesquita-Sousa D, Viegas-Melo D, Martins TF, Monteiro SG, Faccini JLH, Labruna MB, et al. An overview of gamasoidosis caused by Ornithonyssus bursa (Mesostigmata: Macronyssidae) in Brazil and new case records. Int J Acaro/ 2020; 40(7): 1-6. http://dx.doi. org/10.1080/01647954.2020.1810119.

Moller AP. Ectoparasite loads affect optimal clutch size in swallows. Funct Ecol 1991; 5(3): 351-359. http://dx.doi.org/10.2307/2389806.

Moller AP. Host - parasite interactions and vectors in the barn swallow in relation to climate change. Glob Change Biol 2010; 16(4): 1158-1170. http://dx.doi.org/10.1111/j.1365-2486.2009.02035.x.

Mori E, Ancillotto L, Groombridge J, Howard T, Smith VS, Feneru F, et al. Macroparasites of introduced parakeets in Italy: a possible role for parasite-mediated competition. Parasitol Res 2015; 114(9): 3277-3281. http://dx.doi.org/10.1007/s00436-0154548-2. PMid:26025315.

Mori E, Sala JP, Fattorini N, Menchetti M, Montalvo T, Senar JC. Ectoparasite sharing among native and invasive birds in a metropolitan area. Parasitol Res 2019; 118(2): 399-409. http://dx.doi.org/10.1007/s00436-018-6174-2. PMid:30565194.

Morrone J. Biogeographic areas and transition zones of Latin America and the Caribbean Islands based on panbiogeographic and cladistic analyses of the entomofauna. Annu Rev Entomol 2006; 51(1): 467-494. http://dx.doi.org/10.1146/annurev. ento.50.071803.130447. PMid:16332220.

Myers N, Mittermeier RA, Mittermeier CG, da Fonseca GAB, Kent J. Biodiversity hotspots for conservation priorities. Nature 2000; 403(6772): 853-858. http://dx.doi.org/10.1038/35002501. PMid:10706275.

Navarro JL, Martella MB, Bucher EHS. Effects of laying date, clutch size, and communal nest size on the reproductive success of monk parakeets. Wilson Bull 1995; 107(4): 742-746. 
Oliveira CB, Tonin AA, Monteiro SG. Parasitismo do ácaro Ornithonyssus bursa em humanos no Sul do Brasil. Acta Sci Vet 2012; 40(4): 1091.

Olson DM, Dinerstein E. The global 200: A representation approach to conserving the Earth's most biologically valuable ecoregions. Conserv Biol 1998; 12(3): 502-515. http://dx.doi.org/10.1046/j.1523-1739.1998.012003502.x.

Otto JC, Wilson KJ. Assessment of the usefulness of ribosomal 18S and mitochondrial COI sequences in Prostigmata phylogeny. In: Halliday RB, Walter DE, Proctor HC, Norton RA, Colloff MJ, editors. Acarology: Proceedings of the 10th International Congress. Melbourne: CSIRO Publishing; 2001. p. 100-109.

Pérez-García J, Monsalve-Arcila D, Márquez-Villegas C. Presencia de parásitos y enterobacterias en palomas ferales (Columba livia) en áreas urbanas en Envigado, Colombia. Rev Fac Nac Salud Pública 2015; 33(3): 370-376. http://dx.doi.org/10.17533/udea. rfnsp.v33n3a06.

Phillis WA 3rd, Cromroy HL. A preliminary survey of ectoparasitic mites (Acari) of the house sparrow and mockingbird in Florida. Fla Entomol 1972; 55(4): 258. http://dx.doi.org/10.2307/3493376.

Proctor H, Owens I. Mites and birds: diversity, parasitism and coevolution. Trends Ecol Evol 2000; 15(9): 358-364. http://dx.doi. org/10.1016/S0169-5347(00)01924-8. PMid:10931667.

Radovsky FJ. Revision of Genera of the parasitic mite family Macronyssidae (Mesostigmata: Dermanyssoidea) of the world. West Bloomfield, Michigan: Indra Publishing House; 2010.

Santillán MÁ, Grande JM, Liébana MS, Martínez P, Díaz LA, Bragagnolo LA, et al. New hosts for the mite Ornithonyssus bursa in Argentina. Med Vet Entomol 2015; 29(4): 439-443. http://dx.doi.org/10.1111/mve.12129. PMid:26258483.

Schulz JJ, Cayuela L, Echeverria C, Salas J, Rey Benayas JM. Monitoring land cover change of the dryland forest landscape of Central Chile (1975-2008). App/ Geogr 2010; 30(3): 436-447. http://dx.doi.org/10.1016/j.apgeog.2009.12.003.

Selfiannisa F, Susilowati S, Hastutiek P, Suwanti LT, Kusnoto K, Sunarso A. Investation of Ectoparasites In Chickens In Village of Kramat District of Bangkalan Regency of Bangkalan. J Parasit Sci 2018; 2(2): 57-60. http://dx.doi.org/10.20473/jops.v2i2.16400.

Senar JC, Carrillo-Ortiz JG, Ortega-Segalerva A, Dawson Pell FSE, Pascual J, Arroyo L, et al. The reproductive capacity of Monk Parakeets Myiopsitta monachus is higher in their invasive range. Bird Study 2019; 66(1): 136-140. http://dx.doi.org/10.1080/000 63657.2019.1585749.

Sikes RK, Chamberlain RW. Laboratory observations on three species of bird mites. J Parasito/ 1954; 40(6): 691-697. http://dx.doi. org/10.2307/3273713. PMid:13212549.

Smith KF, Acevedo-Whitehouse K, Pedersen AB. The role of infectious diseases in biological conservation. Anim Conserv 2009; 12(1): 1-12. http://dx.doi.org/10.1111/j.1469-1795.2008.00228.x.

Spreyer MF, Bucher EH. Monk parakeet. In: Poole A, Gil F, editors. The birds of North America. Philadelphia, PA, USA: Cornell Lab of Ornithology; 1998. p. 1-23. http://dx.doi.org/10.2173/tbna.322.p.

Sreenivasa Murthy GS, Panda R. Prevalence of Dermanyssus and Ornithonyssus species of mites in poultry farms of Vikarabad area of Hyderabad. J Parasit Dis 2016; 40(4): 1372-1375. http://dx.doi.org/10.1007/s12639-015-0693-x. PMid:27876951.

Strandtmann RW, Wharton GW. Manual of mesostigmatid mites. College Park: The Institute of Acarology, Department of Zoology, University of Maryland; 1958.

Taraschewski H. Hosts and parasites as aliens. J Helminthol 2006; 80(2): 99-128. http://dx.doi.org/10.1079/JOH2006364. PMid:16768855.

Viana IR, Strubbe D, Zocche JJ. Monk parakeet invasion success: a role for nest thermoregulation and bactericidal potential of plant nest material? Biol Invasions 2016; 18(5): 1305-1315. http://dx.doi.org/10.1007/s10530-016-1068-7.

Vitousek PM, Mooney HA, Lubchenco J, Melillo JM. Human domination of Earth's ecosystems. Science 1997; 277(5325): $494-499$. http://dx.doi.org/10.1126/science.277.5325.494.

Vitousek PM. Diversity and biological invasions of oceanic islands. In: Wilson EO, Peter FM, editors. Biodiversity. 14th ed. Washington DC, USA: The National Academies; 1988. p. 181-190. 